\title{
Distinct population structure for co-occurring Anopheles goeldii and Anopheles triannulatus in Amazonian Brazil
}

\author{
Sascha Naomi McKeon ${ }^{1,5} /{ }^{+}$, Marta Moreno², Maria Anise Sallum ${ }^{3}$, \\ Marinete Marins Povoa ${ }^{4}$, Jan Evelyn Conn ${ }^{1,5}$ \\ ${ }^{1}$ Department of Biomedical Sciences, School of Public Health, State University of New York, Albany, NY, USA
2Division of Infectious Diseases, School of Medicine, University of California San Diego, La Jolla, CA, USA
${ }^{3}$ Departamento de Epidemiologia, Faculdade de Saúde Pública, Universidade de São Paulo, São Paulo, SP, Brasil
${ }^{4}$ Laboratório de Pesquisas Básicas em Malária, Instituto Evandro Chagas, Ananindeua, PA, Brasil
${ }^{5}$ Griffin Laboratory, Wadsworth Center, New York State Department of Health, New York, NY, USA
}

To evaluate whether environmental heterogeneity contributes to the genetic heterogeneity in Anopheles triannulatus, larval habitat characteristics across the Brazilian states of Roraima and Pará and genetic sequences were examined. A comparison with Anopheles goeldii was utilised to determine whether high genetic diversity was unique to An. triannulatus. Student $\mathrm{t}$ test and analysis of variance found no differences in habitat characteristics between the species. Analysis of population structure of An. triannulatus and An. goeldii revealed distinct demographic histories in a largely overlapping geographic range. Cytochrome oxidase I sequence parsimony networks found geographic clustering for both species; however nuclear marker networks depicted An. triannulatus with a more complex history of fragmentation, secondary contact and recent divergence. Evidence of Pleistocene expansions suggests both species are more likely to be genetically structured by geographic and ecological barriers than demography. We hypothesise that niche partitioning is a driving force for diversity, particularly in An. triannulatus.

Key words: An. triannulatus - An. goeldii - population structure - COI - white gene - ITS2

Malaria remains one of the most important tropical diseases in the world with an estimated 216 million cases in 2010 (WHO 2011). Brazil has the largest incidence of disease and malaria related deaths in South America, averaging 300 thousand cases annually (MS 2008, Barreto et al. 2009). Nearly all cases occur in the Amazon Basin (Akhavan et al. 1999, Moutinho et al. 2011), where the relatively low levels of transmission have been difficult to control (da Silva-Nunes et al. 2011). The Amazon Basin is one of the world's most important bioregions, with a variety of habitats suitable for Anopheles species, many of which are malaria vectors.

Most primary vectors are widespread because of excellent colonising abilities and adaptation to variable environmental conditions (Costantini et al. 2009, Cohuet et al. 2010, Loaiza et al. 2012). Though not major malaria vectors in South America, Anopheles goeldii and Anopheles triannulatus are locally and regionally important (Rubio-Palis 1994, Póvoa et al. 2001, Galardo et al. 2007) with large geographic distributions and a moderate to wide habitat range (unpublished observations). Both species can colonise and increase abundance in altered or temporary environments (Tadei \& DutaryThatcher 2000). Overlapping species distributions and

doi: 10.1590/0074-0276108052013012

Financial support: IEC/NIH (1T32AI05532901A1), Training in Biodefense and Emerging Infectious Disease/NIH (R01 A154139) (to JEC) + Corresponding author: smckeon@bluecc.edu

Received 17 November 2012

Accepted 16 May 2013 mostly generalist behaviour (McKeon et al. 2013), in addition to the hypothesis of competition towards exclusion, noted by Tadei et al. (1998) make An. goeldii and An. triannulatus ideal comparisons.

An. goeldii (Rozeboom \& Gabaldón), often mistakenly identified as Anopheles nuneztovari (Sallum et al. 2008), has been resurrected from synonymy (Calado et al. 2008) and is part of the Nuneztovari complex (Montoya-Lerma et al. 2011). An. goeldii, thought to be restricted to the Amazon Basin (Calado et al. 2008), may extend further north in sympatry with An. nuneztovari (Scarpassa \& Conn 2011). The close genetic association between An. nuneztovari, an important malaria vector in Colombia and Venezuela (Bourke et al. 2010), and An. goeldii, raises concerns over the putative vector status of the latter and its habitat specificity. Thus, studies involving the population structure and ecological distribution of An. goeldii are useful in determining the extent of its distribution and divergence.

An. triannulatus (Neiva \& Pinto) has been reported from Nicaragua to Argentina (Faran 1980). Originally described as a polymorphic taxon (Faran \& Linthicum 1981), the intraspecific variation was attributed to adaptation to different habitats (Forattini 1962, Faran 1980, Rosa-Freitas et al. 1998). More recently, it has been recognised as a complex of at least three species (Silva-do-Nascimento \& Lourenço-de-Oliveira 2002, Silva-do-Nascimento et al. 2006, 2011). Recent studies showing anthropophilic feeding and biting activity both indoors and out (Brochero et al. 2006, Gutiérrez et al. 2009), support vector incrimination in some areas of Latin America (Silva-do-Nascimento et al. 2006, de Barros et al. 2007). 
As factors affecting speciation and population differentiation evolve at different rates (de Queiroz 2007), local and regional analysis of ecology and population structure may identify behavioural or ecological differences that complement divergence studies. Use of nuclear markers in addition to mitochondrial markers reduces the process error associated with coalescence (Zink \& Barrowclough 2008) and has led to an informal set of genes sequenced frequently for phylogenetic studies including the mitochondrial cytochrome oxidase I (COI) (Avise 2000, Molina-Cruz et al. 2004, Sunghoon et al. 2011), nuclear white gene (Besansky \& Fahey 1997, Reidenbach et al. 2009) and internal transcribed spacer (ITS)2 gene family (Zapata et al. 2007, Shultz \& Wolf 2009, Wiemers et al. 2009). Within the mitochondrial genome the more conservative "folmer region" has become the standard barcode fragment with a $3 \%$ divergence threshold for speciation events (Hebert et al. 2003).

The diversity of Neotropical anophelines has been attributed to the ability of dipterans to readily adapt to and utilise a broad variety of ecological niches (Grimaldi $\&$ Engel 2005) with more generalised populations being more ecologically heterogeneous (Bolnick et al. 2007). Thus, the genetic heterogeneity seen in the Triannulatus and Nuneztovari complexes may be explained, in part, by environmental heterogeneity (Gram \& Sork 2001), including local or microgeographic adaptation, past and present ecological barriers and/or demographic events (Brouat et al. 2004). Additionally, information on the dynamics of larval anophelines is limited (Shililu et al. 2003) and may provide insights into population differences, thereby complementing adult studies.

The purpose of this study was to examine the distribution, abundance and genetics of largely generalist and sympatric species from 76 larval sites to address the following questions: (i) what is the level of habitat differentiation between species, (ii) do patterns of diversity in $A n$. goeldii and An. triannulatus indicate a common cause and (iii) can genetic differentiation be explained by demographic phenomena and (or) geographic boundaries?

\section{MATERIALS AND METHODS}

Mosquito collection - Fourth instar anopheline larvae were collected from 13 localities, including eight in the state of Roraima (RR) in northern Amazonian Brazil and five in the state of Pará (PA) in eastern Amazonian Brazil (Fig. 1, Supplementary data). Sampling was done once for each randomly selected larval site. If the site was positive for anophelines, collections continued for an hour to measure relative species abundance. The study was conducted over three years (2009-2011) during malaria transmission season in each state. The larval sites in RR were located between Amajari and Ecuador, roughly $500 \mathrm{~km}$ along the RR-174, in 2009 and 2011, and in PA between Mojú and Marabá, approximately $560 \mathrm{~km}$ along PA-475/263/150 in 2010. The collection protocol was approved by the Evandro Chagas Institute, Pará State Ethical Committee and the New York State Department of Health, Institutional Review Board. Physical characteristics of the larval habitats were recorded. These included biotic factors such as temperature, alkalinity, $\mathrm{pH}$,

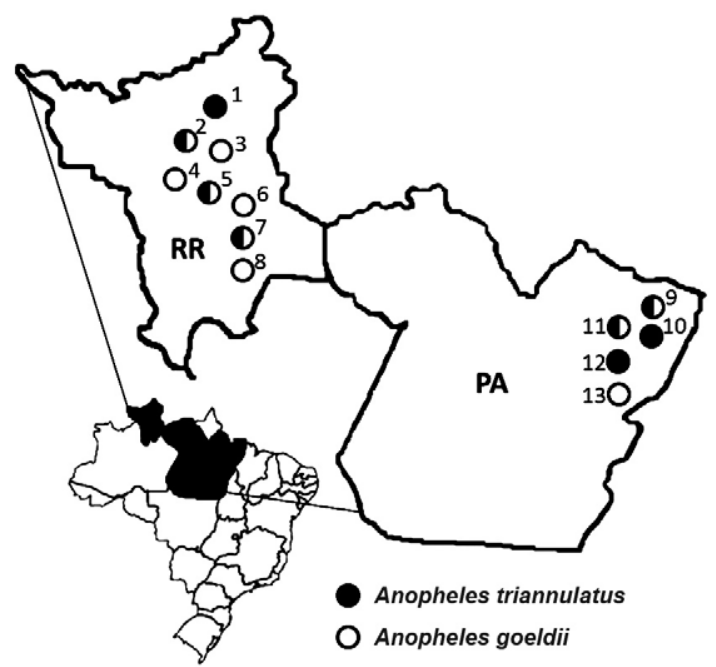

Fig. 1: map of Brazil indicating the location of the 13 localities and species distributions. See Supplementary data for more information. PA: state of Pará; RR: state of Roraima.

conductivity, salinity and turbidity. Additionally, canopy coverage was estimated by spherical densitometer (Minakawa et al. 2005).

Larvae were identified morphologically as An. triannulatus s.l. and An. nuneztovari using the key of Deane et al. (1946) and confirmed by species specific ITS2 restriction fragment length polymorphism (Zapata et al. 2007). Morphological keys do not reflect the recent differences between the Colombian and Venezuelan An. nuneztovari and the Brazilian An. goeldii, samples, therefore samples were sequenced and compared to those from Calado et al. (2008) using a Bayesian inference (BI) phylogenetic approach (data not shown). Total genomic DNA was extracted using the DNeasy Blue Tissue Kit (Qiagen, CA, USA) and maintained at Griffin Laboratory at $-80^{\circ} \mathrm{C}$.

Statistical analysis - A paired sample $t$ test was used to compare An. triannulatus and An. goeldii larval occurrence across all sites. Subsequent analysis of similar larval sites based upon the habitat type and type of water body sampled (pond, pool, swamp etc.), examined variation in larval densities using two-way analysis of variance (ANOVA). Additional analyses examining differences in habitat ecology, based on biotic factors, surrounding vegetation and canopy coverage were examined to test the hypothesis that environmental heterogeneity is positively correlated with genetic diversity.

Amplification and sequencing - A representative sample of one-50 mosquitoes per locality was selected for DNA amplification and sequencing of the COI. Subsets of up to 10 samples per locality for the white gene and up to five for ITS2 were amplified and sequenced. The 658-bp barcode fragment of the COI gene was amplified using the forward primer LCO1490 and the reverse primer HCO2198 (Folmer et al. 1994). Individual polymerase chain reaction (PCR) reactions were performed using Ready-To-Go RT-PCR Beads (Amersham 
Pharmacia/Biotech, NJ, USA) or PCR Supermix High Fidelity (GoTaq, Promega, CA) run on a Bio-Rad PTC100 or 200 series thermal cycler (Bio-Rad Inc), using the conditions stipulated in Hebert et al. (2003). The Applied Genomics Technology Core (Wadsworth Center) carried out the sequencing on an ABI PRISM 3700 automated DNA sequencer. The forward and reverse $\mathrm{COI}$ sequences were aligned using Sequencher 3.0 (Gene Codes Corps, MI, USA), grouped together by sight and trimmed in MEGA v. 3.1 (Kumar et al. 2004) creating a 600-bp fragment. In addition, a subset of three-five $A n$. triannulatus samples from each locality was sequenced following the protocol of Pedro and Sallum (2009), to yield a 449-bp fragment of the 3' COI. High levels of intraspecific variation, deep structure and complex phylogenies based on the 3' end of the COI gene (Moreno et al. 2013) are not congruent with recently described species An. triannulatus, Anopheles haplophylus and An. triannulatus "C" (Silva-do-Nascimento \& Lourençode-Oliveira 2002, Silva-do-Nascimento et al. 2006, 2011). The barcode region is more variable than the $3^{\text {' }}$ end of the COI (Ruiz-Lopez et al. 2012) and able to improve resolution at deeper nodes (Saunders \& Le Gall 2010). Therefore, analyses herein focused on the barcode fragment and included only a subset based on the 3' end to allow systematic comparisons of An. triannulatus populations across Brazil.

Nuclear genes were included to investigate the history of the nuclear genome and provide independent evidence of population divergence (Loiaza et al. 2012). Additionally, nuclear genes do not suffer the short comings of mitochondrial markers (haploid, small genome size, short coalescent time, maternal inheritance) (Ballard \& Whitlock 2004) and are not as biased in base composition (Brower \& De Salle 1998). An 800-bp fragment of the white gene was amplified using the W2R and WF primers, with the PCR conditions as reported in Mirabello and Conn (2008). A 500-bp fragment of the ribosomal ITS2 was amplified using the primers $18 \mathrm{~S}$ and $28 \mathrm{~S}$ following the parameters in $\mathrm{Li}$ and Wilkerson (2005). The PCR products were cleaned, sequenced and aligned creating a 570-bp fragment of the white gene including the intron. The final product size for ITS2 was $433 \mathrm{bp}$ and $371 \mathrm{bp}$ for An. triannulatus and An. goeldii, respectively. A single sequence per individual/gene was included in all subsequent analyses. Haplotypes of heterozygous individuals were inferred for each set of gene sequences using PHASE 2.1 software (Stephens et al. 2001, Stephens \& Donnelly 2003, White et al. 2009). Unique sequences for all markers are available in GenBank (accessions KC167670-KC167816).

Genealogical relationship - Genealogical trees for each species were estimated for the concatenated (COI + white) data set using $\mathrm{BI}$ analysis performed with $\mathrm{Mr}-$ Bayes v. 3.1 (Huelsenbeck \& Ronquist 2001, Ronquist \& Huelsenbeck 2003). Data were partitioned by gene using the model of nucleotide substitution ( $\mathrm{HKY}+\mathrm{I}$ and $\mathrm{TrN}+\mathrm{G}$ for An. triannulatus and $\mathrm{TrN}+\mathrm{I}+\mathrm{G}$ and $\mathrm{TPM} 2 \mathrm{uf}+\mathrm{G}$ for An. goeldii) that best fit the white gene and COI, respectively, determined by jModelTest (Posada 2008). ITS2 sequences were excluded from these analyses because of the limited sample size. The settings were two simultaneous, independent runs of the Markov Chain Monte Carlo for two million generations, sampling every 1,000 generations with a "burnin" of $25 \%$. The outgroup Anopheles marajoara (DQ076221 and AY956296 deposited in GenBank) was chosen based upon its phylogenetic position in Sallum et al. (2000).

Genetic variation - Genetic structure of multiple populations based on statistical parsimony groupings were examined by analysis of molecular variance (AMOVA) using Arlequin v. 3.1.1 (Excoffier et al. 2005) and spatial analysis of molecular variance (SAMOVA), v. 1.0 (Dupanloup et al. 2002). Both algorithms were used to cluster the 600-bp barcode fragment data into genetically and in the case of SAMOVA, geographically, homogeneous populations by generating $F$ statistics $\left(F_{S C}\right.$, $\left.F_{S T}, F_{C T}\right)$. Each species was analysed separately, $A n$. triannulatus into groups of $K=2-16$ and An. goeldii into groups of $K=2-20$, with 1,000 simulated annealing steps from each of 100 sets of initial starting conditions. Groups were based on individual larval sites. A second analysis was undertaken for An. triannulatus using the 449-bp fragment haplotypes of Pedro and Sallum (2009) (GU445849-899 and AF417702) combined with the samples in the present study, to test their hypothesis of geographical sub-structuring within the species based on five populations across Brazil.

Population structure and demographic history - A statistical parsimony network (SPN) estimated genealogical relationships among haplotypes with a $95 \%$ identity for each marker using TCS 1.13 (Clement et al. 2000), except An. goeldii ITS2 sequences, which were examined at $94 \%$ sequence similarity. Homoplasy in all networks was resolved using the algorithm estimation rules in Crandall and Templeton (1993). Estimates of time to coalescence were calculated for the $C O I$ fragment only and compared using $\theta_{S}$ values (Watterson 1975).

The differentiation and polymorphism statistics for COI and white gene sequences by species and locality were computed in DnaSP, v. 5.0 (Librado \& Rozas 2009). Because of the high proportion of shared haplotypes among habitats within a single locality, samples from an individual town/city were pooled to more accurately represent diversity statistics. Furthermore, haplotype distributions across four ecoregions were examined for each of the seven environmental variables to test the hypothesis that climatic differences sustain (and drive) diversity (Hoorn et al. 2010). To test this hypothesis, we considered both the availability of breeding sites and haplotype diversity as measures of gene flow. Individual sites were grouped within ecoregions, based on descriptions from Rosa-Freitas et al. (2007).

The hypothesis of strict neutrality for each species was examined using DnaSP, with the statistics $D_{T}$ (Tajima 1989) and $D$ and $F$ (Fu 1993) evaluating the likelihood of background selection and Fu's $F_{S}$ (Fu 1997) and $R_{2}$ (Ramos-Onsins \& Rozas 2002) examining evidence of population expansion. The mismatch distributions (simulated in Arlequin) were conducted to confirm demographic expansion using sudden and spatial models of 
expansion. Statistically significant differences between observed and simulated distributions were evaluated with the sum of square deviations to reject the hypothesis of demographic expansion (Zarza et al. 2008). Dates of population expansion were estimated for the $C O I$ gene with the formula $T=\tau / 2 u$ (Rogers \& Harpending 1992) using 10 generations per year and the mutation rate of Drosophila estimated at $1 \times 10^{-8}$ substitutions per site per year (Walton et al. 2000, Yang et al. 2011).

\section{RESULTS}

Site diversity and larval abundance - Larvae were predominantly collected from the edges of naturally occurring ponds, comprising $49.19 \%(\mathrm{n}=200)$ of the total Anopheles identified. An. goeldii and An. triannulatus larvae were relatively uncommon in collections from seepages, stream margins and swamps, where they comprised only $10.9 \%$ of the total. Both species were collected from the same site 17 times (Supplementary data). Twelve sites contained An. triannulatus and not An. goeldii, whereas 13 sites contained An. goeldii, but not An. triannulatus. A large proportion, $68.97 \%(\mathrm{n}=140)$, of An. triannulatus larvae were sampled from ponds. An. goeldii larvae appeared equally likely to inhabit artificial pools $(37.93 \%, \mathrm{n}=77)$, ponds $(29.55 \%, \mathrm{n}=60)$ and temporary ditches $(25.12 \%, \mathrm{n}=51)$. No correlations between abundance and habitat type for either species were detected by ANOVA (data not shown).

Habitat characteristics of An. triannulatus and An. goeldii were similar: the 76 sites were not differentiated by larval abundance $(t=-0.2980, d f=42, \mathrm{p}=0.3836)$. ANOVA detected a significant difference in turbidity between sites containing only An. goeldii and those negative for either species $(F=4.89, \mathrm{p}=0.032)$ that was not supported by a $t$ test $(t=1.179, d f=16, p=0.055)$. There are no other significant differences between environmental variables for sites unique for either species and sites either positive or negative for both (Table I).

Genealogical relationship - The concatenated (COI + white gene with intron) BI tree for An. triannulatus, with 50 parsimoniously informative sites, indicated two strongly supported (97 and 98 posterior probabilities) distinct populations of An. triannulatus (Fig. 2). The two populations correspond to the Brazilian states, with the exception of samples from Mojú and Goianésia (9 and 10 , respectively), that were included in the northern group (RR localities). The close relationship between the RR samples and localities Mojú and Goianésia was also evident in the SPN. This may indicate a historical boundary separating north and south populations, with the northern limit occurring just south of the Amazon River and including parts of Goianésia and Mojú. The more derived population 1 corresponds to localities in the Amazon Basin, near the hypothesised population origin (Pedro \& Sallum 2009), with the majority of pop-
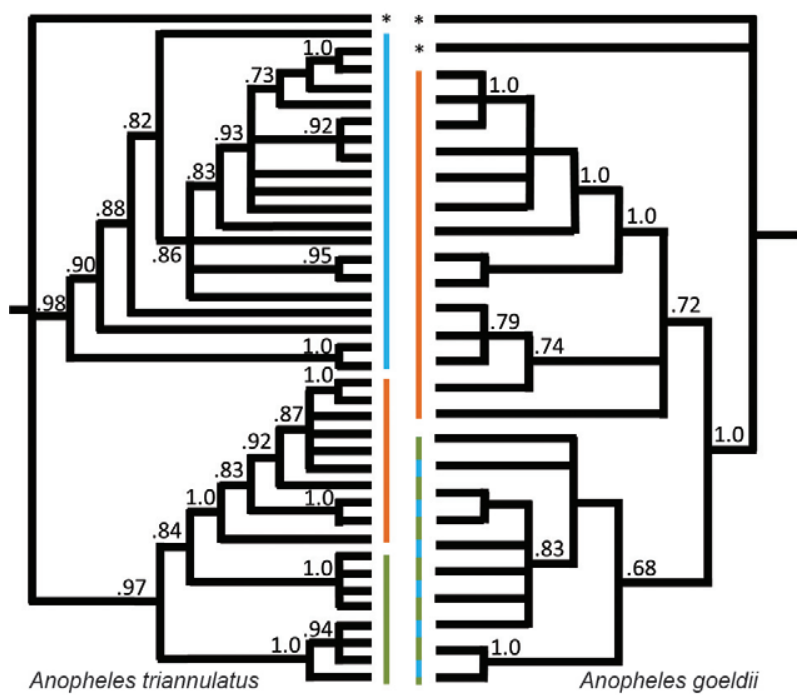

Fig. 2: concatenated (cytochrome oxidase I + white gene) Bayesian inference trees, partitioned by gene using the model of nucleotide substitution that best fit the data as determined by jModelTest. blue: samples from Goianésia, Tucuruí, Jacundá and Marabá [state of Pará (PA)] corresponding to An. triannulatus population 3; green: Mojú and Goianésia samples (PA) in addition to An. triannulatus population 2; orange: localities in the state of Roraima and An. triannulatus population 1. Asterisk means Anopheles marajoara outgroups.

TABLE I

Characteristics ( $\pm 95 \%$ confidence intervals) of habitats with Anopheles triannulatus only, Anopheles goeldii only, both species or neither species present

\begin{tabular}{lcccc}
\hline & An. triannulatus & An. goeldii & Both & Neither \\
\hline Collections (n) & 12 & 13 & 17 & 34 \\
$\mathrm{pH}$ & $5.5 \pm 0.00$ & $5.58 \pm 0.15$ & $5.68 \pm 0.24$ & $5.62 \pm 0.16$ \\
Alkalinity (ppm) & $35 \pm 29.40$ & $33.85 \pm 27.50$ & $47.06 \pm 27.91$ & $52.35 \pm 42.58$ \\
Temperature $\left({ }^{\circ} \mathrm{C}\right)$ & $26.29 \pm 1.37$ & $27.44 \pm 1.88$ & $26.79 \pm 1.10$ & $26.48 \pm 0.95$ \\
Conductivity $(\mu \mathrm{S} / \mathrm{cm})$ & $35.68 \pm 16.33$ & $39.49 \pm 19.68$ & $34.01 \pm 12.93$ & $26.04 \pm 9.76$ \\
Salinity (ppm) & $18.09 \pm 8.13$ & $19.92 \pm 10.31$ & $25.11 \pm 17.34$ & $13.24 \pm 4.90$ \\
Turbidity (JTUs) & $21.67 \pm 15.93$ & $28.46 \pm 16.88$ & $17.50 \pm 6.88$ & $13.09 \pm 5.36$ \\
Canopy coverage $(\%)$ & $11.28 \pm 14.20$ & $13.74 \pm 13.43$ & $13.77 \pm 11.38$ & $10.55 \pm 6.33$ \\
\hline
\end{tabular}


ulation 2 occurring along one of the proposed routes of lineage expansion. Within grouping 2 , smaller subdivisions, related to geography and corresponding to populations 2 and 3, were apparent between haplotypes 9 and 3 that are separated by six mutations and two haplotypes 4 and 1 , separated by two mutations (Fig. 3).

The concatenated $(\mathrm{COI}+$ white gene with intron) $\mathrm{BI}$ tree for An. goeldii, with 32 parsimoniously informative sites, indicated two moderately supported (72 and 68 posterior probabilities) populations which correspond to the Brazilian states (Fig. 2). Unlike An. triannulatus, there does not appear to be any sub-structuring in the samples from PA or support for a separate Goianésia/ Mojú population.

Genetic variation - AMOVA indicated consistently higher $F_{S T}$ and $F_{C T}$ fixation indices across genes and various COI groupings for An. triannulatus, i.e., genetic structuring among and within localities rather than between groups (Table II). However, there was strong genetic differentiation $(41.01 \%)$ also seen in the COI grouping between states, which correlates well with the groups defined by the Bayesian tree.

The small genetic differentiation of An. goeldii between localities suggests panmixia with no significant barriers to gene flow within individual states. AMOVA indicated a large proportion of variation between the two states and among samples from different breeding site types in a given locality (Table II). Genetic structuring in the latter may indicate environmental differences and niche partitioning as drivers of diversity.
SAMOVA analysis for both species found no evidence of a geographic barrier. The addition of the An. triannulatus 449-bp fragment of the COI gene $(\mathrm{n}=35)$ to all samples from Pedro and Sallum (2009) was unable to replicate the five groupings originally described across Brazil.

Population structure and demographic history Analysis of mitochondrial data from 129 An. triannulatus and 133 An. goeldii specimens (Fig. 3) led to the discovery of two very different demographic histories between these sympatric species, which often co-occur within the same larval habitats. The time of the beginning of lineage divergence was calculated following $\mathrm{D}_{\mathrm{a}} / 2 k$, where $\mathrm{D}_{\mathrm{a}}$ is the average nucleotide divergence between lineages and $2 k$ is the divergence rate (Heckel et al. 2005). We utilised the mutation rate of Drosophila (Walton et al. 2000, Yang et al. 2011) to estimate these parameters and their significance based on the coalescence (DnaSP v. 5.10) (Librado \& Rozas 2009) and MEGA v. 5.1 (Tamura et al. 2011).

A parsimony network for An. triannulatus indicated that a minimum of six mutational steps separate three potential populations based on geography (Fig. 3). The most common haplotypes were $1(\mathrm{n}=18), 2(\mathrm{n}=15)$, $3(\mathrm{n}=11)$ and $6(\mathrm{n}=9)$ (Fig. 3), with seven haplotypes (15.6\%) shared among localities and 38 (84.4\%) unique (Supplementary data). Overall, An. triannulatus was consistent with a category I phylogeographic pattern (Avise 2000) characterised by pronounced genetic gaps between spatially circumscribed haplogroups. A high proportion of singletons $(23,51.1 \%)$, in addition to in-

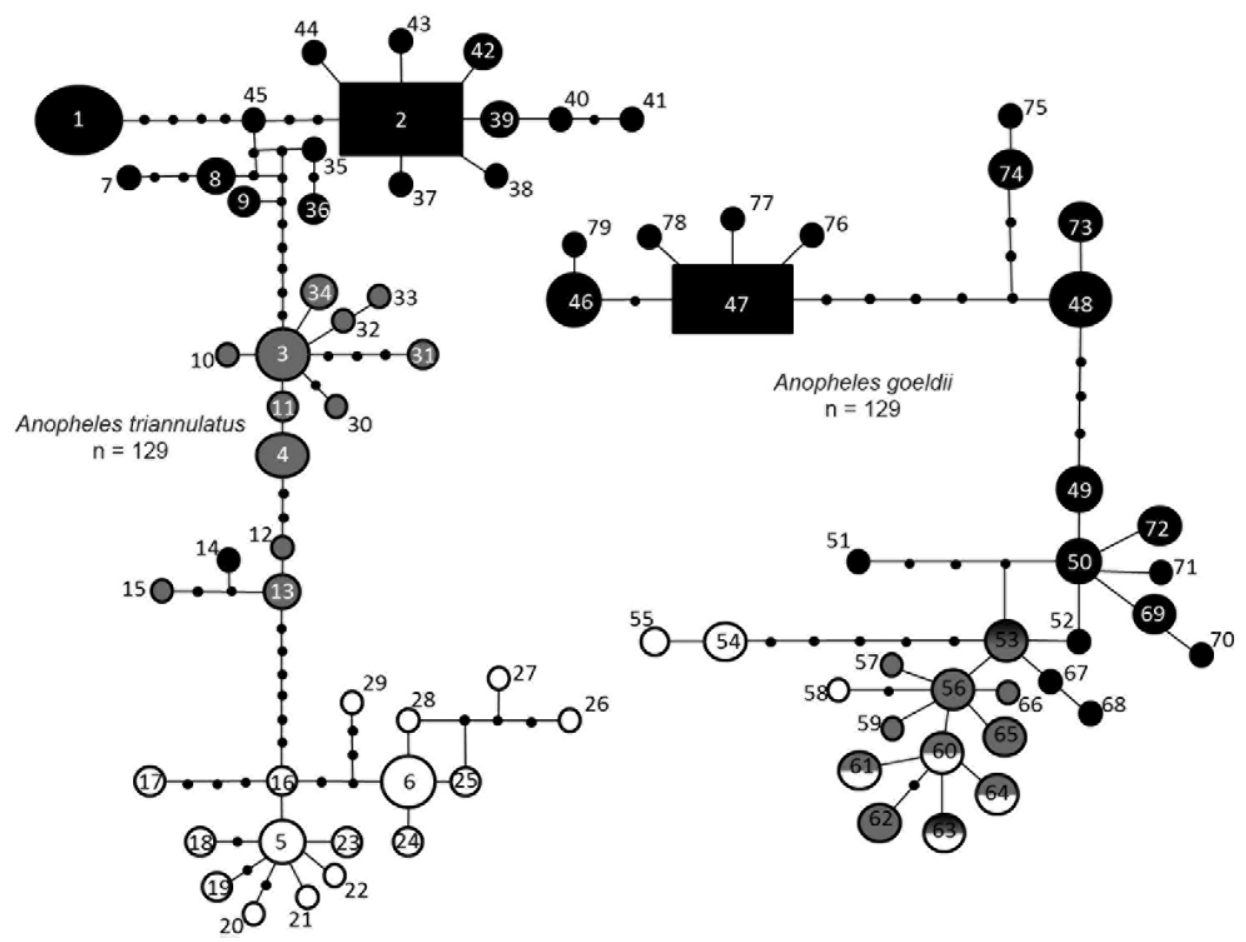

Fig. 3: statistical parsimony network of cytochrome oxidase I sequences at $95 \%$ support. black: localities in the state of Roraima; grey: Mojú and Goianésia samples from the state of Pará (PA); n: number of sequences; white: samples from Goianésia, Tucuruí, Jacundá and Marabá (PA). For An. triannulatus, black refers to population 1, grey (with the addition of haplotype 14) to population 2 and white to population 3. 
TABLE II

Analysis of molecular variance calculations for inter and intravariation among species and populations for various markers

\begin{tabular}{|c|c|c|c|c|c|}
\hline \multirow[b]{2}{*}{ Gene } & \multirow[b]{2}{*}{ Source of variation } & \multicolumn{2}{|c|}{ Anopheles triannulatus } & \multicolumn{2}{|c|}{ Anopheles goeldii } \\
\hline & & $\begin{array}{c}\text { Variance } \\
(\%)\end{array}$ & $\begin{array}{l}\text { Fixation } \\
\text { index }\end{array}$ & $\begin{array}{c}\text { Variance } \\
(\%)\end{array}$ & $\begin{array}{l}\text { Fixation } \\
\text { index }\end{array}$ \\
\hline \multirow[t]{3}{*}{ COI } & Between RR and PA & 41.01 & $\mathrm{~F}_{\mathrm{CT}}=0.41^{a}$ & 45.12 & $\mathrm{~F}_{\mathrm{CT}}=0.45^{b}$ \\
\hline & Among localities within states & 29.23 & $\mathrm{~F}_{\mathrm{SC}}=0.50^{b}$ & 5.29 & $\mathrm{~F}_{\mathrm{SC}}=0.10^{b}$ \\
\hline & Within a given locality & 29.76 & $\mathrm{~F}_{\mathrm{ST}}=0.70^{b}$ & 49.59 & $\mathrm{~F}_{\mathrm{ST}}=0.50^{b}$ \\
\hline \multirow[t]{3}{*}{ white } & Between RR and PA & -3.01 & $\mathrm{~F}_{\mathrm{CT}}=-0.03^{c}$ & 89.46 & $\mathrm{~F}_{\mathrm{CT}}=0.89^{a}$ \\
\hline & Among localities within states & 58.62 & $\mathrm{~F}_{\mathrm{SC}}=0.57^{b}$ & 0.42 & $\mathrm{~F}_{\mathrm{SC}}=0.04^{c}$ \\
\hline & Within a given locality & 44.38 & $\mathrm{~F}_{\mathrm{ST}}=0.56^{b}$ & 10.12 & $\mathrm{~F}_{\mathrm{ST}}=0.90^{b}$ \\
\hline \multirow[t]{3}{*}{$\mathrm{COI}$} & Between SPN populations & 38.85 & $\mathrm{~F}_{\mathrm{CT}}=0.39^{c}$ & - & - \\
\hline & Among localities & 33.92 & $\mathrm{~F}_{\mathrm{SC}}=0.55^{b}$ & - & - \\
\hline & Within a given locality & 27.23 & $\mathrm{~F}_{\mathrm{ST}}=0.73^{b}$ & - & - \\
\hline
\end{tabular}

$a: \mathrm{p}<0.05 ; b: \mathrm{p}<0.001 ; c$ : not significant; COI: cytochrome oxidase I; PA: state of Pará; RR: state of Roraima; SPN: statistical parsimony network derived groupings.

dividual populations within An. triannulatus containing star-shaped nodes (surrounding haplotypes 2, 3 and 5), supports demographic expansions, background selection or selective sweeps (Slatkin \& Hudson 1991, Fu 1997). Based upon the 600-bp fragment, $D_{a}$ between the northern and southern states is 0.0118 [standard deviation $(\mathrm{SD})=0.003$ ]. Therefore, the estimated divergence is $437,500-737,500$ years ago, in the Pleistocene. The two PA populations had a $D_{a}=0.014(\mathrm{SD}=0.004)$, indicating more ancestral divergence (congruent with Bayesian tree), approximately 500,000-900,000 years ago.

$A n$. goeldii COI is consistent with a category III phylogeographic pattern (Avise 2000) where most haplotypes are closely related, yet some geographic localisation exists. The most common haplotypes were $46(\mathrm{n}=21), 47$ ( $=33)$ and $48(n=13)$ (Fig. 3$)$, with 14 haplotypes $(41.2 \%)$ shared among localities, and $20(58.8 \%)$ unique (Supplementary data). Similar to An. triannulatus, there was a relatively high proportion of singletons $(14,41.2 \%)$, indicating a demographic expansion, background selection or selective sweep (Slatkin \& Hudson 1991, Fu 1997), particularly in PA (singletons arising from haplotype 56). In contrast, haplotypes from RR exhibited longer branches, missing haplotypes and a near equal distribution of shared haplotypes and single mutations, consistent with a signal of an older lineage with balancing selection (Fig. 3). $D$ between northern and southern states is 0.008 (SD $=0.002$ ). Therefore, the estimated divergence is 316,000 516,500 years ago (Pleistocene).

Networks of An. triannulatus nuclear data (white gene and ITS2) indicate a history of contractions and expansions. Similar to the COI gene, the ITS2 network depicts a category I pattern whereas the white gene reveals a much more homogeneous haplotype distribution. Overall, the white gene follows a category II intraspecific pattern, with pronounced gaps between some branches and some clustering of anciently separated geographic populations (Fig. 4).

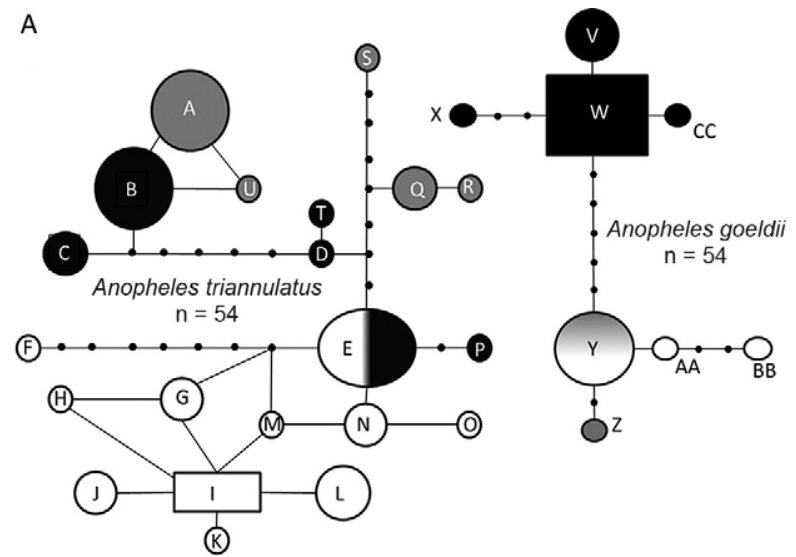

B

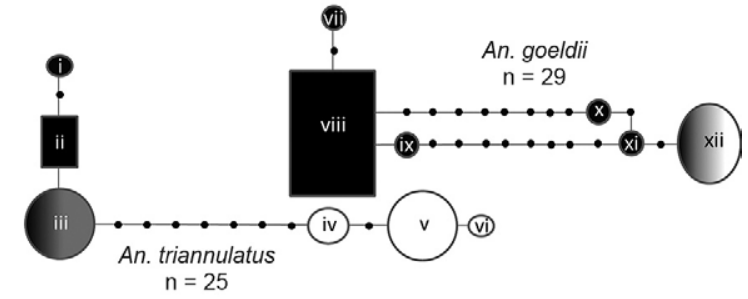

Fig. 4: statistical parsimony network of white gene (A) and internal transcribed spacer 2 sequences (B) at 95\%, except ITS2 An. goeldii which is at $94 \%$ sequence support. black: localities in the state of Roraima; grey: Mojú and Goianésia samples from the state of Pará (PA); $\mathrm{n}$ : number of sequences; white: samples from Goianésia, Tucuruí, Jacundá and Marabá (PA).

Networks of An. goeldii nuclear data (white gene and ITS2) reveal distinct geographical populations. The white gene has a distinct category I pattern separated by five mutational steps, while the ITS2 haplotype clusters (Fig. 4) are less pronounced, but still correspond primarily to RR and PA with a few outliers. Polymorphism analyses 
of the $C O I$ sequences found haplotype and nucleotide diversity was greater among An. triannulatus populations (Supplementary data) in contrast to An. goeldii.

Genetic polymorphism analyses of the $C O I$ sequences indicated that haplotype and nucleotide diversity was greater among An. triannulatus populations (Supplementary data) in contrast to An. goeldii. The white gene exhibited lower nucleotide diversities compared to COI, but surprisingly An. triannulatus continued to demonstrate high haplotype diversity (Supplementary data), which combined with relatively low nucleotide diversity may signal a rapid expansion (Avise 2000, de Jong et al. 2011). High COI variation between states and geographic populations is strongly supported by population differentiation statistics (Table III), although the $G_{S T}$ values were low, suggesting a history of gene flow (Table III).

In general, neutrality tests were negative for both species (Table IV), suggesting an excess of rare polymorphisms consistent with either negative/positive selection or an increase in population size, although only one of these tests $(F)$ was significant for An. triannulatus, i.e., populations 2 and 3. Mismatch distribution for sudden expansions did not support this finding and, instead, revealed marginally significant expansion patterns for only population 1, corresponding to RR. Sudden and spatial populations for An. goeldii could not be rejected (Fig. 5). Estimated expansions for both species are during the Pleistocene, An. triannulatus 129,693 years ago $(59,857-194,877)$ and An. goeldii 112,387 years ago (17,111-187,449).

\section{DISCUSSION}

Distribution patterns of mosquito species are dependent on the availability of suitable aquatic habitats (Grillet 2000). Overlapping geographic distributions, in addition to the absence of significant difference in species abundance across sampled habitats, suggest that An. goeldii is a suitable comparison species for An. triannulatus. The lack of any significant differentiation between sympatric habitats, to those unique to a species or absent of either, suggests these species may be more broadly adapted (Eisenberg et al. 2000, Chase \& Knight 2003). However, co-occurrence of species does not imply the same ability to exploit shared habitats (Diabate et al. 2005).

The combined sequence results support distinct demographic histories for the two species despite similar distribution and larval habitat co-occurrence. Across molecular markers An. goeldii consistently depicts two moderately supported populations corresponding to the two Brazilian states, however, An. triannulatus appears to have undergone historical fragmentation, subsequent secondary contact and homogenisation followed by more recent divergence due to allopatry. Either environmental changes (e.g., habitat availability and climatic oscillations) alone cannot account for population divergence or differences in biology allow these two species to respond differently to climatic oscillations.

The clear separation of populations based on Brazilian states in An. goeldii strongly supports the alternative hypothesis of geographic isolation driving divergence rather than environmental changes. While often contest- ed in the neotropics, the Pleistocene refugia hypothesis (Haffer 1969) postulates that climatic fluctuations resulted in the fragmentation of continuous forest into refuges separated by expanses of grass-dominated savannah or desert. Alternatively, the Miocene marine incursion hypothesis suggests sea level changes during the late Tertiary (23.7-1.8 million years ago) created three isolated regions: the Brazilian Shield, the Guiana Shield and the eastern Andean slopes (Webb 1995, Bates 2001, Hoorn et al. 2010). The last commonly explored mechanism of divergence is the riverine barrier hypothesis, where major rivers act as barriers to gene flow, thus promoting speciation between populations on either side (Wallace 1852, Aleixo 2004, Mirabello \& Conn 2008).

Although no boundary was indicated by SAMOVA, this does not discount the possibility that an historical boundary existed, separating north and south populations. Although one study found evidence for waterways over $4 \mathrm{~km}$ wide being complete barriers to gene flow (Pedro \& Sallum 2009), others have determined that the Amazon is not an effective barrier (Fairley et al. 2002, Mirabello \& Conn 2008) and that geographic distance and/or differing demographic histories may be the main forces responsible for partitioning genetic variation (Mirabello \& Conn 2008).

The discrepancy regarding the inclusion of Mojú and some of Goianésia among An. triannulatus RR population, but their inclusion with geographically similar PA samples in An. goeldii may be attributed to individual species' responses to dispersal opportunities (Brouat et al. 2004). The two An. triannulatus populations identified in Goianésia could also be the result of a suture zone.

\section{TABLE III}

Inter and intrapopulation differentiation of Anopheles triannulatus and Anopheles goeldii populations based on statistical parsimony network

Comparison

\begin{tabular}{lccc}
\hline \multicolumn{3}{c}{ An. triannulatus } & An. goeldii \\
\hline & RR vs. PA & Three populations & RR vs. PA \\
\hline $\mathrm{H}_{\mathrm{S}}$ & $0.89^{a}$ & $0.86^{a}$ & $0.86^{a}$ \\
$K_{S}^{*}$ & $1.77^{a}$ & $1.41^{a}$ & $1.60^{a}$ \\
$Z^{*}$ & $7.43^{a}$ & $7.00^{a}$ & $7.83^{a}$ \\
$\mathrm{~S}_{\mathrm{nn}}$ & $0.99^{a}$ & $1.00^{a}$ & $0.97^{a}$ \\
$\chi^{2}$ & $129^{a}$ & $258^{a}$ & $125.84^{a}$ \\
$\mathrm{G}_{\mathrm{ST}}$ & 0.06 & 0.09 & 0.045 \\
$\mathrm{~K}_{\mathrm{t}}$ & 10.09 & 10.09 & 7.43 \\
\hline
\end{tabular}

$\overline{a: \mathrm{p}<0.0001 ; G_{S T}: \text { genetic differentiation; } H_{S}: \text { genetic differen- }}$ tiation based on haplotype data; $K_{S}{ }^{*}$ : differentiation based on sequence data; $K_{t}$ : average number of nucleotide differences; $\mathrm{n}$ : number of total individuals compared; PA: state of Pará; RR: state of Roraima; $S_{n n}$ : measures how often the nearest neighbours of sequences are found in the same population; $\chi^{2}$ : genetic differentiation based on allele frequencies; $Z^{*}$ : rank statistic to analyse sequence similarity. 
TABLE IV

Multiple statistical analyses evaluating the probability for a recent population expansion

\begin{tabular}{lcccccc}
\hline Species & $\mathrm{n}$ & $D_{T}$ & $D^{a}$ & $F^{a}$ & $F_{S}$ & $R_{2}$ \\
\hline Anopheles triannulatus & 129 & -0.22187 & -1.28038 & -0.99732 & $-10.329^{a}$ & 0.08650 \\
$\quad$ Roraima & 57 & -0.37846 & -1.32424 & -1.17022 & -1.488 & 0.09200 \\
Pará & 72 & -0.47543 & -0.97094 & -0.93438 & -5.842 & 0.08900 \\
$\quad$ Population 1 & 56 & -0.08718 & -1.11433 & -0.88956 & -1.209 & 0.10200 \\
$\quad$ Population 2 & 36 & -1.06921 & -0.55581 & -0.85324 & $-3.582^{a}$ & 0.07770 \\
$\quad$ Population 3 & 37 & -1.02686 & -0.40080 & -0.71980 & $-4.809^{a}$ & 0.07800 \\
Anopheles goeldii & 133 & -0.30013 & -1.24177 & -1.01960 & -5.867 & 0.08260 \\
Roraima & 103 & 0.06971 & -1.6295 & -1.1537 & -1.677 & 0.0989 \\
Pará & 30 & -0.0415 & 0.15645 & 0.11023 & -3.321 & 0.1185 \\
\hline
\end{tabular}

a: significance, $\mathrm{p}<0.50 ; D$ : Fu and Li's $D$ (Fu 1993); $D_{T}$ : Tajima's $D$ (Tajima 1989); F: Fu and Li's $F$ (Fu 1993); F $:$ Fu's Fs (Fu 1997); n: sample size; $R_{2}$ : Ramos-Onsin's and Roza's $R_{2}$ (Ramos-Onsins \& Rozas 2002).

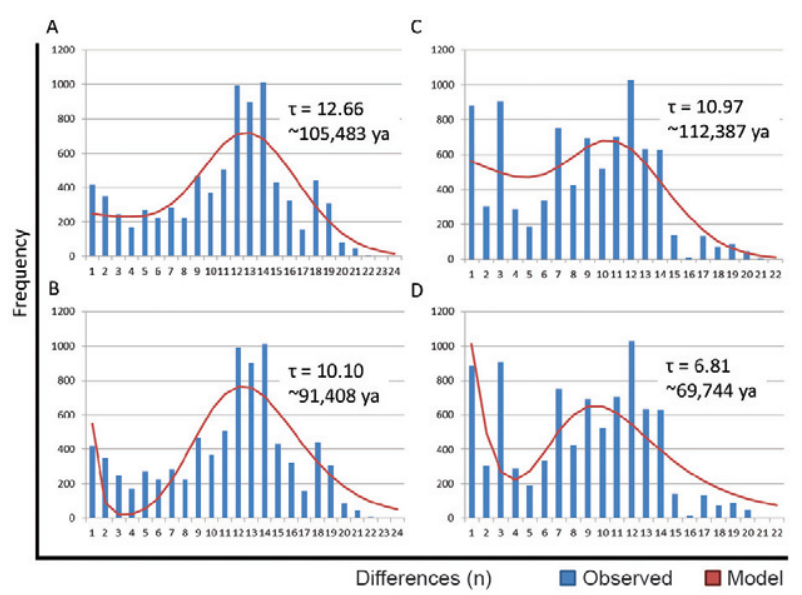

Fig. 5: representative mismatch distributions with calculated $\tau$ and estimated time of sudden expansion. Bars indicate observed values. Line represents the model for all Anopheles triannulatus (A), all Anopheles goeldii (B), An. triannulatus population 2 (C) (Mojú and Goianésia samples) and An. triannulatus population 3 (D) (Goianésia, Tucuruí and Jacundá samples). ya: years ago.

Species dispersal activity and differential selection can cause hybrid zones to appear mobile and settle as boundaries between environments or in regions of low population density (Barton \& Hewitt 1985, Mallet 1993, 2010). Suture zones that span several species suggest divergence was driven by a common influence of environmental change (Morgan et al. 2010). Further evaluation of species in the Goianésia area could resolve the contribution of environmental change to population diversity.

Overlapping geographic distributions, in addition to the absence of significant difference in species abundance across sampled habitats, implies little habitat differentiation between species and a broad ecological range. Although biological differences may drive divergence uniquely in each of these sympatric species, a common cause for diversity patterns cannot be ruled out.
Geographic boundaries/distance, variation in dispersal activity and ecological range may each contribute to the distinct patterns of divergence seen in An. triannulatus and An. goeldii. As species complexes are common in anophelines, additional studies are needed to resolve the extent of divergence. Continued studies using multiple markers at a local and continental scale will resolve the status of speciation and may clarify what role, if any, a given population, lineage or species has on malaria transmission, because population differences influence peak biting times, feeding preferences and vectorial capacity (Lounibos \& Conn 2000).

\section{ACKNOWLEDGEMENTS}

To Dr Povoa's research group, at Evandro Chagas Institute, and to Dr Freddy Ruiz, Walter Reed Army Institute of Research, for assistance in mosquito collection and logistics, and to Sara Bickersmith, Wadsworth Center, New York State Department of Health, and Dr Jose Loiaza, Smithsonian Tropical Research Institute, for comments and assistance interpreting results.

\section{REFERENCES}

Akhavan D, Musgrove P, Abrantes A, d'A Gusmão R 1999. Cost-effective malaria control in Brazil. Cost-effectiveness of a Malaria Control Program in the Amazon basin of Brazil, 1988-1996. Soc Sci Med 49: 1385-1399.

Aleixo A 2004. Historical diversification of a terra-firme forest bird super species: a phylogeographic perspective on the role of different hypotheses of Amazonian diversification. Evolution 58: 1303-1317.

Avise JC 2000. Phylogeography. The history and formation of species, University Press, Massachusetts, 447 pp.

Ballard JWO, Whitlock MC 2004. The incomplete natural history of mitochondria. Mol Ecol 13: 729-744.

Barreto ML, Teixeira MG, Bastos FI, Ximenes RAA, Barata RB, Rodrigues LC 2009. Sucessos e fracassos no controle de doenças infecciosas no Brasil: o contexto social e ambiental, políticas, intervenções e necessidades de pesquisa. Available from: download.thelancet.com/flatcontentassets/pdfs/brazil/brazilpor3.pdf.

Barton NH, Hewitt GM 1985. Analysis of hybrid zones. Annu Rev Ecol Syst 16: 113-148. 
Bates JM 2001. Avian diversification in Amazonia: evidence for historical complexity and a vicariance model for a basic diversification pattern. In I Viera, MA D'Incao, JM Cardoso da Silva, D Oren (eds.), Diversidade biológica e cultural da Amazônia, Museu Paraense Emílio Goeldi, Belém, p. 11-9138.

Besansky NJ, Fahey GT 1997. Utility of the white gene in estimating phylogenetic relationships among mosquitoes (Diptera: Culicidae). Mol Biol Evol 14: 442-454.

Bolnick DI, Svanback R, Araujo MS, Persson L 2007. Comparative support for the niche variation hypothesis that more generalized populations also are more heterogeneous. Proc Natl Acad Sci USA 104: 10075-10079.

Bourke BP, Foster PG, Bergo ES, Calado DC, Sallum MAM 2010. Phylogenetic relationships among species of Anopheles (Nyssorhynchus) (Diptera, Culicidae) based on nuclear and mitochondrial gene sequences. Acta Trop 114: 88-96.

Brochero H, Pareja PX, Ortiz G, Olano VA 2006. Breeding places and biting activity of Anopheles species in the municipality of Cimitarra, Santander, Colombia. Biomedica 26: 269-277.

Brouat C, Chevallier H, Meusnier S, Noblecourt T, Rasplus JY 2004. Specialization and habitat: spatial and environmental effects on abundance and genetic diversity of forest generalist and specialist Carabus species. Mol Ecol 13: 1815-1826.

Brower AVZ, De Salle R 1998. Patterns of mitochondrial versus nuclear DNA sequence divergence among nymphalid butterflies: the utility of wingless as a source of characters for phylogenetic inference. Insect Mol Biol 7: 73-82.

Calado DC, Foster PG, Bergo ES, dos Santos CLS, Galardo AKR, Sallum MAM 2008. Resurrection of Anopheles goeldii from synonymy with Anopheles nuneztovari (Diptera, Culicidae) and a new record for Anopheles dunhami in the Brazilian Amazon. Mem Inst Oswaldo Cruz 103: 791-799.

Chase JM, Knight TM 2003. Drought-induced mosquito outbreaks in wetlands. Ecol Lett 6: 1017-1024.

Clement M, Posada D, Crandall KA 2000. TCS: a computer program to estimate gene genealogies. Mol Ecol 9: 1657-1659.

Cohuet A, Harris C, Robert V, Fontenille D 2010. Evolutionary forces on Anopheles: what makes a malaria vector. Trends Parasitol 26: 130-136.

Costantini C, Ayala D, Guelbeogo WG, Pombi M, Some CY, Bassole IHN, Ose K, Fosting JM, Sagnon NF, Fontenille D, Besansky NJ, Simard F 2009. Living at the edge: biogeographic patterns of habitat segregation conform to speciation by niche expansion in Anopheles gambiae. BMC Ecol 9: 16.

Crandall KA, Templeton AR 1993. Empirical tests of some preditions from coaslescent theory with applications to intraspecific phylogeny reconstruction. Genet 134: 959-969.

da Silva-Nunes M, Moreno M, Conn JE, Gamboa D, Abeles S, Vinetz JM, Ferreira MU 2011. Amazonian malaria: asymptomatic human reservoirs, diagnostic challenges, environmentally driven changes in mosquito vector populations and the mandate for sustainable control strategies. Acta Trop 121: 281-291.

de Barros FSM, de Aguiar DB, Rosa-Freitas MG, Luitgards-Moura JF, da Costa Gurgel H, Honorio NA, de Arruda ME, Tsouris P, Vasconcelos SD 2007. Distribution summaries of malaria vectors in the northern Brazilian Amazon. J Vector Ecol 32: 161-167.

de Jong MA, Wahlberg N, van Eijk M, Brakefield PM, Zwaan BJ 2011. Mitochondrial DNA signature for range-wide populations of Bicyclus anynana suggests a rapid expansion from recent refugia. PLoS ONE 6: e21385. de Queiroz K 2007. Species concepts and species delimitation. Syst Biol 56: 879-886.

Deane LM, Causey OR, Deane MP 1946. An illustrated key by adult female characteristics for identification of thirty-five species of Anophelini with notes on the malaria vectors (Diptera: Culicidae). In Studies on Brazilian anophelines from the Northeast and Amazon Regions, monographic series 18, The American Journal of Hygiene, Baltimore, p. 1-18.

Diabate A, Dabire RK, Kim EH, Dalton R, Millogo N, Baldet T, Simard S, Gimnig JE, Hawley WA, Lehmann T 2005. Larval development of the molecular forms of Anopheles gambiae (Diptera: Culicidae) in different habitats: a transplantation experiment. $J$ Med Entomol 42: 548-553.

Dupanloup I, Schneider S, Excoffier L 2002. A simulated annealing approach to define the genetic structure of populations. Mol Ecol 11: $2571-2581$

Eisenberg JNS, Washburn JO, Schreiber SJ 2000. Generalist feeding behaviors of Aedes sierrensis larvae and their effects on protozoan populations. Ecology 81: 921-935.

Excoffier L, Laval G, Schmeider S 2005. Arlequin version 3.0: an integrated software package for population genetic data analysis. Evol Bioinform Online 1: 47-50.

Fairley TL, Póvoa MM, Conn JE 2002. Evaluation of the Amazon River delta as a barrier to gene flow for the regional malaria vector, Anopheles aquasalis (Diptera: Culicidae) in northeastern Brazil. J Med Entomol 39: 861-869.

Faran ME 1980. Mosquito studies (Diptera, Culicidae). XXXIV. A revision of the Albimanus section of the subgenus Nyssorhynchus of Anopheles. Contrib Amer Ent Inst 15: 1-215.

Faran ME, Linthicum KJ 1981. A handbook of the Amazonian species of Anopheles (Nyssorhynchus) (Diptera: Culicidae). Mosq Syst 13: 1-81.

Folmer O, Black M, Hoeh W, Lutz R, Vrijenhoek R 1994. DNA primers for amplification of mitochondrial cytochrome $\mathrm{c}$ oxidase subunit I from diverse metazoan invertebrates. Mol Mar Biol Biotechnol 3: 294-297.

Forattini OP 1962. Entomologia médica, Vol. 1, Universidade de São Paulo, São Paulo, 416 pp.

Fu YX 1993. Statistical tests of neutrality of mutations. Genetics 133: 693-709.

Fu YX 1997. Statistical tests of neutrality of mutations against population growth, hitchhiking and background selection. Genetics 147: 915-925.

Galardo AKR, Arruda M, D'Almeida, Couto AAR, Lounibos LP, Zimmerman R 2007. Malaria vector incrimination in three rural riverine villages in the Brazilian Amazon. Am J Trop Med Hyg 76: 461-469.

Gram WK, Sork VL 2001. Association between environmental and genetic heterogeneity in forest tree populations. Ecology 82: 2012-2021.

Grillet ME 2000. Factors associated with distribution of Anopheles aquasalis and Anopheles oswaldoi (Diptera: Culicidae) in a malarious area, northeastern Venezuela. J Med Entomol 37: 231-238.

Grimaldi D, Engel MS 2005. Evolution of the insects, Cambridge University Press, Cambridge, 772 pp.

Gutiérrez LA, González JJ, Gómez GF, Castro MI, Rosero DA, Luckhart S, Conn JE, Correa MM 2009. Species composition and natural infectivity of anthropophilic Anopheles (Diptera: Culicidae) in the states of Córdoba and Antioquia, northwestern Colombia. Mem Inst Oswaldo Cruz 104: 1117-1124. 
Haffer J 1969. Speciation in Amazonian forest birds. Science 165: 131-137.

Hebert PDN, Cywinska A, Ball SL, de Waard JR 2003. Biological identifications through DNA barcodes. Proc R Soc Lond B Biol Sci 270: 313-321.

Heckel G, Burri R, Fink S, Desmet JF, Excoffier L 2005. Genetic structure and colonization processes in European populations of the common vole, Microtus arvalis. Evolution 59: 2231-2242.

Hoorn C, Wesselingh FP, ter Steege H, Bermudez MA, Mora A, Sevink J, Sanmartín I, Sanchez-Meseguer A, Anderson CL, Figueiredo JP, Jaramillo C, Riff D, Negri FR, Hooghiemstra H, Lundberg J, Stadler T, Sarkinen T, Antonelli A 2010. Amazonia through time: Andean uplift, climate change, landscape evolution and biodiversity. Science 330: 927-931.

Huelsenbeck JP, Ronquist F 2001. MrBayes: Bayesian inference of phylogeny. Bioinformatics 17: 754-755.

Kumar S, Tamura K, Nei M 2004. MEGA3: integrated software for molecular evolutionary genetics analysis and sequence alignment. Brief Bioinform 5: 150-163.

Li C, Wilkerson RC 2005. Identification of Anopheles (Nyssorhynchus) albitarsis complex species (Diptera: Culicidae) using rDNA internal transcribed spacer 2-based polymerase chain reaction primes. Mem Inst Oswaldo Cruz 100: 495-500.

Librado P, Rozas J 2009. DnaSP v. 5: a software for comprehensive analysis of DNA polymorphism data. Bioinformatics 25: 1451-1452.

Loaiza JR, Bermingham E, Sanjur OI, Scott ME, Bickersmith SA, Conn JE 2012. Review of genetic diversity in malaria vectors (Culicidae: Anophelinae). Infect Genet Evol 12: 1-12.

Lounibos LP, Conn JE 2000. Malaria vector heterogeneity in South America. Am Entomol 46: 238-249.

Mallet J 1993. Speciation, raciation and color pattern evolution in Heliconius butterflies: evidence from hybrid zones. In RG Harrison, Hybrid zones and the evolutionary process, Oxford University Press, New York, p. 226-260.

Mallet J 2010. Shift happens! Shifting balance and the evolution of diversity in warning colour and mimicry. Ecol Entomol 35: 90-104.

McKeon SN, Schlichting CD, Povoa MM, Conn JE 2013. Ecological suitability and spatial distribution of five Anopheles species in Amazonian Brazil. Am J Trop Med Hyg 88: 1079-1086.

Minakawa N, Munga S, Atieli F, Mushinzimana E, Goufa Zhou, Githeko AK, Yan G 2005. Spatial distribution of anopheline larval habitats in western Kenyan highlands: effects of land cover types and topography. Am J Trop Med Hyg 73: 157-165.

Mirabello L, Conn JE 2008. Population analysis using the nuclear white gene detects Pliocene/Pleistocene lineage divergence within Anopheles nuneztovari in South America. Med Vet Entomol 22: $109-119$.

Molina-Cruz A, de Mérida AM, Mill K, Rodríguez F, Schoua C, Yurrita MM, Molina E, Palmieri M, Black WC 2004. Gene flow among Anopheles albimanus populations in Central America, South America and the Caribbean assessed by microsatellites and mitochondrial DNA. Am J Trop Med Hyg 71: 350-359.

Montoya-Lerma J, Solarte YA, Giraldo-Calderón GI, Quiñones ML, Ruiz-López F, Wilkerson RC, González R 2011. Malaria vector species in Colombia - A review. Mem Inst Oswaldo Cruz 106 (Suppl. I): 223-238.

Moreno M, Bickersmith S, Harlow W, Hildebrandt J, McKeon SN, Silva-do-Nascimento TF, Loaiza JR, Ruiz F, Lourenço-de-Oliveira R, Sallum MAM, Bergo ES, Fritz GN, Wilkerson RC, Linton
YM, Dantur Juri MJ, Rangel Y, Povoa MM, Gutierrez-Builes LA, Correa MM, Conn JE 2013. Phylogeography of the neotropical Anopheles triannulatus complex (Diptera: Culicidae) supports deep structure and complex patterns. Parasit Vectors 6: 47.

Morgan K, Linton YM, Somboon P, Saikia P, Dev V, Socheat D, Walton C 2010. Inter-specific gene flow dynamics during the Pleistocene-dated speciation of forest-dependent mosquitoes in Southeast Asia. Mol Ecol 19: 2269-2285.

Moutinho PR, Gil LHS, Cruz RB, Ribolla PEM 2011. Population dynamics, structure and behavior of Anopheles darlingi in a rural settlement in the Amazon rainforest of Acre, Brazil. Malar J 10: 174.

MS - Ministério da Saúde 2008. Situação epidemiológica da Malária no Brasil 2008. [cited 2012 Aug 8]. Available from: portal.saude. gov.br/portal/arquivos/pdf/folder_malaria_2008_final.pdf.

Pedro PM, Sallum MA 2009. Spatial expansion and population structure of the Neotropical malaria vector, Anopheles darlingi (Diptera: Culicidae). Biol J Linn Soc 97: 854-866.

Posada D 2008. jModelTest: Phylogenetic model averaging. Mol Biol Evol 25: 1253-1256.

Póvoa MM, Wirtz RA, Lacerda RNL, Miles MA, Warhurst D 2001. Malaria vectors in the municipality of Serra do Navio, state of Amapá, Amazon Region, Brazil. Mem Inst Oswaldo Cruz 96: 179-184.

Ramos-Onsins SE, Rozas J 2002. Statistical properties of new neutrality tests against population growth. Mol Biol Evol 19: 2092-2100.

Reidenbach KR, Cook S, Bertone MA, Harbach RE, Wiegmann BM, Besansky NJ 2009. Phylogenetic analysis and temporal diversification of mosquitoes (Diptera: Culicidae) based on nuclear genes and morphology. BMC Evol Biol 9: 298.

Rogers AR, Harpending H 1992. Population growth makes waves in the distribution of pairwise genetic differences. Mol Biol Evol 9: 552-569.

Ronquist F, Huelsenbeck JP 2003. MrBayes 3: Bayesian phylogenetic inference under mixed models. Bioinformatics 19: 1572-1574.

Rosa-Freitas MG, Lourenço-de-Oliveira R, de Carvalho-Pinto CJ, Flores-Mendoza C, Silva-do-Nascimento TF 1998. Anopheline species complexes in Brazil. Current knowledge of those related to malaria transmission. Mem Inst Oswaldo Cruz 93: 651-655.

Rosa-Freitas MG, Tsouris P, Peterson AT, Honório NA, de Barros FSM, de Aguiar DB, Gurgel HC, de Arruda ME, Vasconcelos SD, Luitgards-Moura JF 2007. An ecoregional classification for the state of Roraima, Brazil. The importance of landscape in malaria biology. Mem Inst Oswaldo Cruz 102: 349-357.

Rubio-Palis Y 1994. Variation of the vectorial capacity of some anophelines in western Venezuela. Am J Trop Med Hyg 50: 420-424.

Ruiz-Lopez F, Wilkerson RC, Conn JE, McKeon SN, Levin DM, Quiñones ML, Póvoa MM, Linton YM 2012. DNA barcoding reveals both known and novel taxa in the Albitarsis group (Anopheles: Nyssorhynchus) of Neotropical malaria vectors. Parasit Vectors 5: 44.

Sallum MAM, Marrelli MT, Nagaki SS, Laporta GZ, dos Santos CLS 2008. Insight into Anopheles (Nyssorhynchus) (Diptera: Culicidae) species from Brazil. J Med Entomol 45: 970-981.

Sallum MAM, Schultz TR, Wilkerson RC 2000. Phylogeny of anophelinae (Diptera: Culicidae) based on morphological characters. Ann Entomol Soc Am 93: 745-775.

Saunders GW, Le Gall L 2010. Editorial. Cryptogamie Algol 31: 373-375.

Scarpassa VM, Conn JE 2011. MtDNA tracks a complex evolutionary history with Pleistocene divergence for the Neotropical malaria vector Anopheles nuneztovari sensu lato. Am J Trop Med Hyg 85: 857-867. 
Schultz J, Wolf M 2009. ITS2 sequence-structure analysis in phylogenetics: a how-to manual for molecular systematics. Mol Phylogenet Evol 52: 520-523.

Shililu J, Ghebremeskel T, Seulu F, Mengistu S, Fekadu H, Zerom M, Ghebregziabiher A, Sintasath D, Bretas G, Mbogo C, Githure J, Brantly E, Novak R, Beier JC 2003. Larval habitat diversity and ecology of anopheline larvae in Eritrea. $J$ Med Entomol 40: 921-929.

Silva-do-Nascimento TF, Lourenço-de-Oliveira R 2002. Anopheles halophylus, a new species of the subgenus Nyssorhynchus (Diptera: Culicidae) from Brazil. Mem Inst Oswaldo Cruz 97: 801-811.

Silva-do-Nascimento TF, Pitaluga LDR, Peixoto AA, Lourenço-de-Oliveira R 2011. Molecular divergence in the timeless and cpr genes among three sympatric cryptic species of the Anopheles triannulatus complex. Mem Inst Oswaldo Cruz 106 (Suppl. I): 218-222.

Silva-do-Nascimento TF, Wilkerson RC, Lourenço-de-Oliveira R, Monteiro FA 2006. Molecular confirmation of the specific status of Anopheles halophylus (Diptera: Culicidae) and evidence of a new cryptic species within An. triannulatus in central Brazil. $J$ Med Entomol 43: 455-459.

Slatkin M, Hudson RR 1991. Pairwise comparisons of mitochondrial DNA sequences in stable and exponentially growing populations. Genetics 129: 555-562.

Stephens M, Donnelly P 2003. A comparison of Bayesian methods for haplotype reconstruction from population genotype data. $\mathrm{Am} \mathrm{J}$ Hum Genet 73: 1162-1169.

Stephens M, Smith NJ, Donnelly P 2001. A new statistical method for haplotype reconstruction from population data. Am J Hum Genet 68: $978-989$

Sunghoon J, Duwal RK, Lee S 2011. COI barcoding of true bugs (Insecta, Heteroptera). Mol Ecol Resour 11: 266-270.

Tadei WP, Dutary-Thatcher B 2000. Malaria vectors in the Brazilian Amazon: Anopheles of the subgenus Nyssorhynchus. Rev Inst Med Trop Sao Paulo 42: 87-94.

Tadei WP, Dutary-Thatcher B, Santos JM, Rodrigues IB, Rafael MS 1998. Ecologic observations on anopheline vectors of malaria in the Brazilian Amazon. Am J Trop Med Hyg 59: 325-335.

Tajima F 1989. Statistical method for testing the neutral mutation hypothesis by DNA polymorphism. Genetics 123 : 585-595.
Tamura K, Peterson D, Peterson N, Stecher G, Nei M, Kumar S 2011. MEGA5: Molecular Evolutionary Genetics Analysis using Maximum Likelihood, Evolutionary Distance and Maximum Parsimony Methods. Mol Biol Evol 28: 2731-2739.

Wallace AR 1852. On the monkeys of the Amazon. Proceedings of Zoological Society of London 20: 107-110.

Walton C, Handley JM, Tun-Lin W, Collins FH, Harbach RE, Baimai V, Butlin RK 2000. Population structure and population history of Anopheles dirus mosquitoes in Southeast Asia. Mol Biol Evol 17: 962-974.

Watterson GA 1975. On the number of segregating sites in genetic models without recombination. Theor Popul Biol 7: 256-276.

Webb SD 1995. Biological implications of the middle Miocene Amazon seaway. Science 269: 361-362.

White BJ, Cheng C, Sangaré D, Lobo NF, Collins FH, Besansky NJ 2009. The population genomics of trans-specific inversion polymorphisms in Anopheles gambiae. Genetics 183: 275-288.

WHO - World Health Organization 2011. World Malaria Report 2011. Available from: who.int/malaria/world_malaria report_2011/9789241564403_eng.pdf.

Wiemers M, Keller A, Wolf M 2009. ITS2 secondary structure improves phylogeny estimation in a radiation of blue butterflies of the subgenus Agrodiaetus (Lepidoptera: Lycaenidae: Polyommatus). BMC Evol Biol 9: 300.

Yang M, Ma Y, Wu J 2011. Mitochondrial genetic differentiation across populations of the malaria vector Anopheles lesteri from China (Diptera: Culicidae). Malar J 10: 216.

Zapata MA, Cienfuegos AV, Quiros OI, Quinones ML, Luckhard S, Correa MM 2007. Discrimination of seven Anopheles species from San Pedro de Uraba, Antioquia, Colombia, by polymerase chain reaction-restriction fragment length polymorphism analysis of ITS sequences. Am J Trop Med Hyg 77: 67-72.

Zarza E, Reynoso VH, Emerson BC 2008. Diversification in the northern neotropics: mitochondrial and nuclear DNA phylogeography of the iguana Ctenosaura pectinata and related species. Mol Ecol 17: 3259-3275.

Zink RM, Barrowclough GF 2008. Mitochondrial DNA under siege in avian phylgeography. Mol Ecol 17: 2107-2121. 
TABLE

Species distribution of anopheline larvae in different larval habitats by locality over three transmission seasons (2009-2011)

\begin{tabular}{|c|c|c|c|}
\hline Locality & Habitat type & $\begin{array}{l}\text { Anopheles triannulatus } \\
\text { (n) }\end{array}$ & $\begin{array}{l}\text { Anopheles goeldii } \\
\text { (n) }\end{array}$ \\
\hline \multirow[t]{2}{*}{ Amajarí (1) } & Marsh & 0 & 0 \\
\hline & Pool & 1 & 1 \\
\hline \multirow[t]{5}{*}{ Alto Alegre (2) } & Ditch & 0 & 0 \\
\hline & Marsh & 4 & 0 \\
\hline & Pond & 0 & 7 \\
\hline & Seepage & 0 & 0 \\
\hline & Stream margin & 2 & 1 \\
\hline \multirow[t]{6}{*}{ Boa Vista (3) } & Ditch & 0 & 0 \\
\hline & Marsh & 0 & 0 \\
\hline & Pond & 0 & 4 \\
\hline & Pool & 0 & 14 \\
\hline & Seepage & 0 & 6 \\
\hline & Stream margin & 0 & 0 \\
\hline \multirow{2}{*}{ Mucajaí (4) } & Ditch & 0 & 0 \\
\hline & Pool & 0 & 62 \\
\hline \multirow[t]{2}{*}{ Iracema (5) } & Ditch & 10 & 45 \\
\hline & Pond & 40 & 11 \\
\hline \multirow[t]{3}{*}{ Petrolina (6) } & Ditch & 0 & 0 \\
\hline & Pond & 0 & 0 \\
\hline & Stream margin & 0 & 3 \\
\hline \multirow[t]{2}{*}{ Martins Pereira (7) } & Stream margin & 1 & 2 \\
\hline & Swamp & 14 & 4 \\
\hline \multirow[t]{4}{*}{ Ecuador (8) } & Pond & 0 & 2 \\
\hline & Seepage & 0 & 5 \\
\hline & Stream margin & 0 & 0 \\
\hline & Swamp & 0 & 0 \\
\hline \multirow[t]{3}{*}{ Mojú (9) } & Pond & 19 & 19 \\
\hline & Marsh & 66 & 31 \\
\hline & Stream margin & 0 & 0 \\
\hline \multirow[t]{5}{*}{ Goianésia (10) } & Marsh & 0 & 0 \\
\hline & Pond & 14 & 0 \\
\hline & Pool & 0 & 0 \\
\hline & Stream margin & 0 & 0 \\
\hline & Swamp & 0 & 0 \\
\hline \multirow[t]{2}{*}{ Tucuruí (11) } & Pond & 7 & 2 \\
\hline & Stream margin & 6 & 0 \\
\hline \multirow[t]{3}{*}{ Jacundá (12) } & Marsh & 5 & 0 \\
\hline & Pond & 11 & 0 \\
\hline & Stream margin & 0 & 2 \\
\hline \multirow[t]{4}{*}{ Marabá (13) } & Ditch & 0 & 6 \\
\hline & Marsh & 0 & 0 \\
\hline & Pond & 2 & 3 \\
\hline & Stream margin & 1 & 0 \\
\hline Total & & 203 & 230 \\
\hline
\end{tabular}

1-13: see Fig. 1 for more information. 
TABLE

Description of shared cytochrome oxidase I haplotypes and genetic polymorphism statistics for Anopheles triannulatus and Anopheles goeldii

\begin{tabular}{|c|c|c|c|c|c|c|c|}
\hline & Site & $\mathrm{n}$ & Haplotypes & $\pi(\mathrm{SD})$ & $1-\sum f_{i}^{2}(\mathrm{SD})$ & $P$ & $K$ \\
\hline \multirow[t]{9}{*}{ An. triannulatus } & 1 & 1 & 1 & - & - & - & - \\
\hline & 2 & 4 & $1(\mathbf{2}), 40,41$ & $0.01(0.00)$ & $0.83(0.22)$ & 12 & 7.67 \\
\hline & 5 & 37 & 1 (15), 2 (6), 7, 8, 9 (2), 35, 36 (2), 37, 39 (4), 43, 45 & $0.01(0.00)$ & $0.80(0.05)$ & 20 & 5.61 \\
\hline & 7 & 15 & $2(9), 14,38,42(3), 44$ & $0.00(0.00)$ & $0.63(0.13)$ & 14 & 2.27 \\
\hline & 9 & 30 & $3(11), 4(7), 10,11,30,31(2), 32,33,34(4)$ & $0.00(0.00)$ & $0.81(0.05)$ & 12 & 1.95 \\
\hline & 10 & 14 & $\mathbf{6}(\mathbf{3}), 12,13(3), 15, \mathbf{1 6}, 17(2), \mathbf{2 4}, \mathbf{2 5}, 28$ & $0.01(0.00)$ & $0.92(0.05)$ & 20 & 6.99 \\
\hline & 11 & 13 & $5(2), 6,16,18,19,20,21,22,26,27$ & $0.01(0.00)$ & $0.96(0.04)$ & 16 & 4 \\
\hline & 12 & 15 & $5(4), 6(4), 23(2), 24,25$ (2), 29 & $0.01(0.00)$ & $0.83(0.06)$ & 9 & 2.99 \\
\hline & & 129 & & $0.02(0.00)$ & $0.95(0.01)$ & 57 & 10.1 \\
\hline \multirow[t]{10}{*}{ An. goeldii } & 2 & 4 & $46,47(3)$ & $0.00(0.00)$ & $0.50(0.27)$ & 2 & 1 \\
\hline & 3 & 15 & $46(4), 47(7), 48,49,77,78$ & $0.01(0.00)$ & $0.74(0.09)$ & 15 & 3.26 \\
\hline & 4 & 18 & $46(3), 47(6), 48(2), 49(2), 50,63,67,72$ & $0.01(0.00)$ & $0.86(0.06)$ & 18 & 6.78 \\
\hline & 5 & 50 & $\begin{array}{c}46(7), 47(14), 48(10), 49(3), 50(2), 51,52,63(3) \\
70,71,73(2), 74(2), 75\end{array}$ & $0.01(0.01)$ & $0.86(0.03)$ & 24 & 6.29 \\
\hline & 6 & 3 & $47(2), 72$ & $0.01(0.01)$ & $0.67(0.31)$ & 11 & 7.33 \\
\hline & 7 & 6 & $\mathbf{4 6}, \mathbf{5 0}, 68, \mathbf{6 9}, \mathbf{7 3}, 76$ & $0.01(0.00)$ & $1.00(0.10)$ & 18 & 8.47 \\
\hline & 8 & 7 & $46(5), 47,53$ & $0.01(0.00)$ & $0.52(0.21)$ & 12 & 3.81 \\
\hline & 9 & 17 & $\mathbf{5 3}, \mathbf{5 6}, 57,59,60$ (2), 61 (3), $62(2), \mathbf{6 4}, 65,66$ & $0.00(0.00)$ & $0.93(0.04)$ & 10 & 2.18 \\
\hline & 11 & 2 & 54,63 & - & - & - & - \\
\hline & 13 & 11 & $54(3), 55(2), 58,60,63(2), 64$ & $0.01(0.00)$ & $0.91(0.07)$ & 13 & 5.6 \\
\hline & & 133 & & $0.01(0.01)$ & $0.90(0.002)$ & 44 & 7.43 \\
\hline
\end{tabular}

$K$ : average number of differences; $\mathrm{n}$ : number of sequences; $P$ : polymorphic sites; SD: standard deviation; $1-\Sigma f_{i}^{2}$ : haplotype diversity; П: nucleotide diversity; 1-13: see Fig. 1 for more information. Bold indicates shared haplotypes and indicates diversity among lineages or species.

TABLE

Description of shared white haplotypes and genetic polymorphism statistics for Anopheles triannulatus and Anopheles goeldii

\begin{tabular}{|c|c|c|c|c|c|c|c|}
\hline Species & Site & $\mathrm{n}$ & Haplotypes & $\pi(\mathrm{SD})$ & $1-\sum f_{i}^{2}(\mathrm{SD})$ & $P$ & $K$ \\
\hline \multirow[t]{9}{*}{ An. triannulatus } & 1 & 1 & $\mathbf{B}$ & - & - & - & - \\
\hline & 2 & 3 & $\mathbf{B}, \mathbf{E}(2)$ & - & - & - & - \\
\hline & 5 & 10 & $\mathbf{B}(3), \mathbf{C}(4), \mathrm{D}(2), \mathbf{E}$ & $0.00(0.00)$ & $0.51(0.16)$ & 7 & 2.47 \\
\hline & 7 & 4 & $\mathbf{E}(2), \mathrm{P}, \mathrm{T}$ & - & - & - & - \\
\hline & 9 & 9 & $\mathrm{~A}(8), \mathrm{U}$ & $0.00(0.00)$ & $0.22(0.17)$ & 1 & 0.22 \\
\hline & 10 & 9 & $\mathbf{E}, \mathrm{N}(2), \mathrm{O}, \mathrm{Q}(3), \mathrm{R}, \mathrm{S}$ & $0.01(0.00)$ & $0.81(0.12)$ & 9 & 3.94 \\
\hline & 11 & 10 & $\mathbf{E}, \mathrm{F}, \mathbf{I}, \mathbf{J}(2), \mathbf{K}, \mathbf{L}(2), \mathbf{N}(2)$ & $0.01(0.00)$ & $0.93(0.06)$ & 11 & 4.02 \\
\hline & 12 & 8 & G (2), H, I, J, L (2), M & $0.00(0.00)$ & $0.93(0.08)$ & 4 & 1.54 \\
\hline & & 54 & & $0.01(0.00)$ & $0.93(0.02)$ & 24 & 5.43 \\
\hline \multirow[t]{8}{*}{ An. goeldii } & 2 & 4 & $\mathbf{V}, \mathbf{W}(2), \mathrm{CC}$ & - & - & - & - \\
\hline & 3 & 10 & $\mathbf{V}(3), \mathbf{W}(6), X$ & $0.00(0.00)$ & $0.600(0.13)$ & 4 & 1.07 \\
\hline & 4 & 10 & $\mathbf{V}, \mathbf{W}(9)$ & $0.00(0.00)$ & $0.20(0.15)$ & 1 & 0.20 \\
\hline & 5 & 9 & W (9) & $0.00(0.00)$ & $0.000(0.00)$ & 0 & 0 \\
\hline & 8 & 1 & W & - & - & - & - \\
\hline & 9 & 10 & $\mathbf{Y}(9), \mathrm{Z}$ & $0.00(0.00)$ & $0.200(0.15)$ & 2 & 0.4 \\
\hline & 13 & 8 & $\mathbf{Y}(5), \mathrm{AA}(2), \mathrm{BB}$ & $0.00(0.00)$ & $0.61(0.16)$ & 3 & 1.04 \\
\hline & & 52 & & $0.01(0.00)$ & $0.66(0.05)$ & 12 & 2.85 \\
\hline
\end{tabular}

$K$ : average number of differences; $\mathrm{n}$ : number of sequences; $P$ : polymorphic sites; SD: standard deviation; $1-\Sigma f_{i}^{2}$ : haplotype diversity; П: nucleotide diversity; 1-13: see Fig. 1 for more information. Bold indicates diversity among lineages or species. 